\title{
Carmustine in Ethanol
}

National Cancer Institute

\section{Source}

National Cancer Institute. Carmustine in Ethanol. NCl Thesaurus. Code C2602.

A formulation containing carmustine dissolved in ethanol for intra-tumoral administration that allows carmustine to enter both aqueous and lipid compartments of the target tissue. As an antineoplastic nitrosourea, carmustine alkylates and cross-links DNA during all phases of the cell cycle, resulting in disruption of DNA function, cell cycle arrest, and apoptosis. Carmustine also carbamoylates proteins, including DNA repair enzymes, resulting in an enhanced cytotoxic effect. Carmustine is highly lipophilic and crosses the blood-brain barrier readily. 